\title{
Phytoplankton of the lberá system
}

\author{
Marina E. Forastier* \& Yolanda Zalocar de Domitrovic \\ With 5 figures and 1 table
}

\begin{abstract}
The Iberá system is one of the largest wetlands in South America with scarce anthropic disturbances. In this Mesopotamic region waters have low conductivity and the main nutrients are generally present in low concentrations. The shallow lakes of the Iberá system are surrounded by extensive swamps by which streams circulate. Phytoplankton density showed seasonal variations, with minima in autumn-winter and maxima in spring-summer. The northeastern shallow lakes were characterised by their high density with dominance of Cyanobacteria. The reduction in phytoplankton density and increase of diversity towards the south of the system was related to the development of submerged vegetation. Phytoplankton density was higher in the limnetic area, where light and nutrient availability is enhanced in relation to the vegetated area. The Iberá system presented more than 1000 algal taxa and thus, it is one of the wetlands of higher diversity in South America. This complex system is a potential center of dispersion of species from the Argentine Mesopotamia.
\end{abstract}

Keywords: phytoplankton diversity, endemism, wetlands, Esteros del Iberá

\section{Introduction}

The northeast of Argentina, delimited by the large rivers of the La Plata basin, presents numerous aquatic environments, with varied limnological characteristics and a very diverse phycoflora (Tell 2014). The Paraguay-Paraná fluvial axis, with a north-south direction, separates the Chaco-Pampean plain region, towards the west (Tell 2014), from the Argentine Mesopotamia, towards the east. The Iberá system (RAMSAR site), one of Argentina's largest wetlands $\left(27^{\circ} 30^{\prime}, 28^{\circ} 45^{\prime} \mathrm{S}\right.$ and $\left.58^{\circ} 00^{\prime}, 57^{\circ} 30^{\prime} \mathrm{W}\right)$, is located in this section. The catchment area of the Iberá wetland has a size of about $14000 \mathrm{~km}^{2}$. With a NE-SW direction, it has a triangular shape of around $250 \mathrm{~km}$ in length and $20-140 \mathrm{~km}$ in width (Ferrati et al. 2005). The difference in water level along the entire length of the triangle is only $20 \mathrm{~m}$, with an average slope of 1/10000 (Canziani et al. 2006). The natural exit of its waters is produced through the Corriente River, which runs into the Middle Paraná River (Fig. 1).

Authors' address:

Centro de Ecología Aplicada del Litoral, Facultad de Ciencias Exactas y Naturales y Agrimensura, Universidad Nacional del Nordeste, CC 291, CP 3400 Corrientes, Argentina.

* Corresponding author: marinaforaster@hotmail.com 


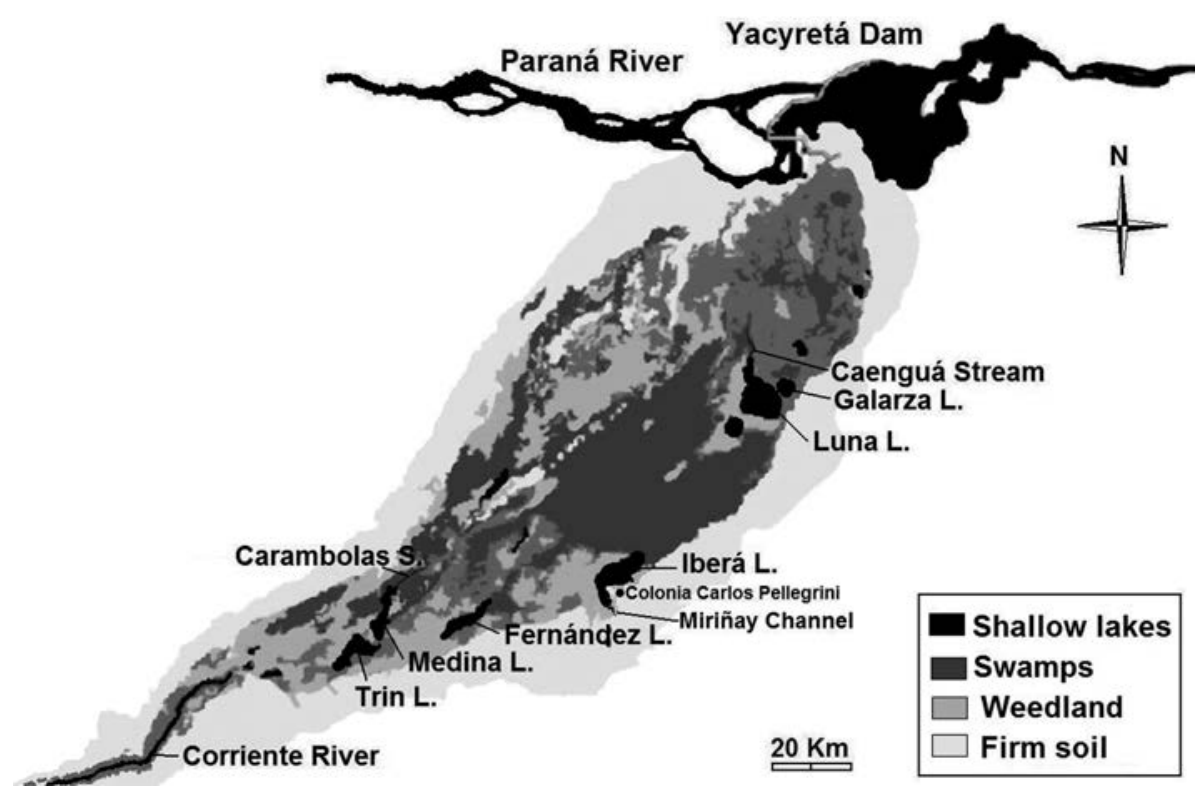

Fig. 1. Geographic location of the Iberá system in Corrientes province (Argentina).

The limnological studies in this region are scarce because of its limited accessibility (CECOAL 1981, Poi de Neiff 2003, Cózar et al. 2003, Neiff 2004). The roads and human settlements are in the wetland border.

In this article, we include the limnological characteristics and phytoplankton of the main lenitic and lotic environments of the Iberá system (called 'Esteros del Iberá'), one of the few wetlands in South America with scarce anthropic disturbances.

\section{The Iberá system}

The Iberá system has a subtropical humid climate (Bruniard 1981). The annual mean temperature is $\sim 20^{\circ} \mathrm{C}$. The mean rainfall is $1200 \mathrm{~mm} /$ year, with a higher frequency and concentration of rains in summer and autumn. The distribution of dry and wet periods is modified during the El Niño/La Niña events (Neiff 2004). Ninety per cent of the surface is permanently or temporary flooded, from which $80 \%$ is covered by vegetation. The shallow lakes of the system are surrounded by extended swamps by which the streams, with channels defined in organic soils, circulate. There is a high production of aquatic and amphibian vegetation and a low transference rate to other trophic levels, leading to a continuous accumulation of organic matter in the ecosystem (Neiff 2004). The difference in flooded surfaces between the maximum and minimum water availability in the system is low, increasing from the eastern to the western section (Neiff 2003a). 


\section{Lenitic environments}

\section{Shallow lakes}

The shallow lakes have little depth ( $2-5 \mathrm{~m})$, sub-rounded (e.g. Luna and Galarza lakes, etc.) or elongated shapes with their major axis parallel to the drainage axis (Fernández, Medina and Trin lakes). They are surrounded by swamps with 'embalsados' in their borders (Fig. 2). The physical and chemical characteristics of waters differ between the limnetic and the vegetated areas in each shallow lake and also with waters from the marginal swamps (Lancelle 2003, Neiff 2003a). The submerged aquatic vegetation occupies extensive areas, particularly towards the south of the system, where it covers more than 50\% of the surface in the Fernández, Medina and Trin lakes.

Water transparency is high (Table 1). The Secchi disk reaches approximately $75 \%$ of the depth in non-windy days, being even higher at sites densely vegetated by submerged macrophytes (Neiff 2004). pH shows acid to neutral values, with higher values in spring and summer due to the high photosynthetic activity of phytoplankton and submerged plants. The dissolved oxygen concentration is high (exceeds $60 \%$ saturation), related to frequent mixing caused by wind action. In calm days, there is a difference of up to $2^{\circ} \mathrm{C}$ between the surface and the bottom (Neiff 2003a). The water is characterised by low mineralization and nutrient concentration. The shallow lakes are settled on fluvial sediments of the Paraná River old channel (Popolizio 1977, Orfeo 2005). These very lixiviated soils were suggested as the cause of the low nutrient content (Neiff 2004). Moreover, in shallow lakes, submerged macrophytes contribute to nutrient reduction (mainly N) of the water column (Scheffer 1998).

Northeastern shallow lakes. These shallow lakes are analyzed based on information obtained in samplings carried out in 1977-1980 (Zalocar de Domitrovic 2003) and compared to studies in 2007-2008. The Luna and Galarza lakes have extensive marginal swamps areas with inflowing channels in the north extreme. The water of the Galarza Lake, with a smaller surface and lower depth, circulates into the Luna Lake, larger and deeper. These shallow lakes do not show urban settlements in their periphery and are far from the anthropic action, although they were previously affected by rice culture.

Phytoplankton structure was similar in both shallow lakes. Cyanobacteria (Oscillatoriales $>$ Nostocales $>$ Chroococcales), Chlorophyceae (Chlorococcales $>$ Desmidiaceae), Bacillariophyceae (centrics $>$ pennates) and Cryptophyceae characterised this community (Fig. 3). Density showed minima in autumn-winter and maxima in spring-summer. Shade-tolerant

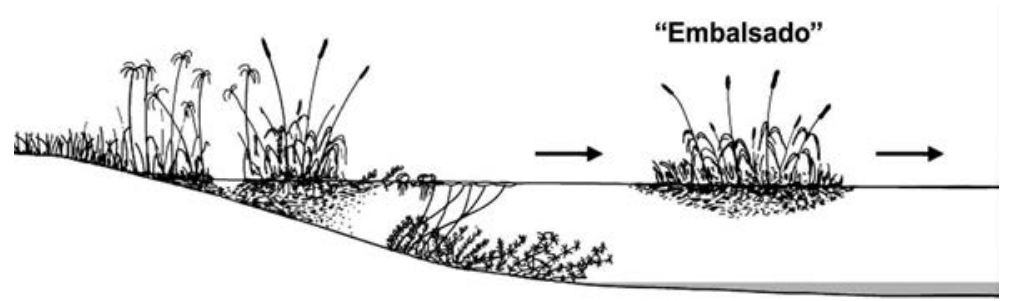

Fig. 2. Profile of shallow lakes' border constituted by macrophytes and 'embalsados'. Embalsado: Floating island made up of marshy vegetation supported by low-density organic soils (Neiff 2003a). 
宝言

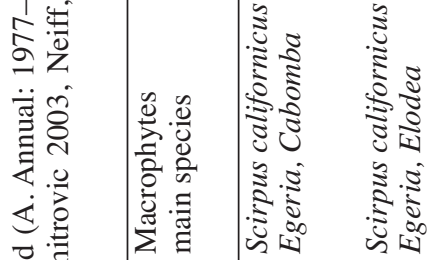

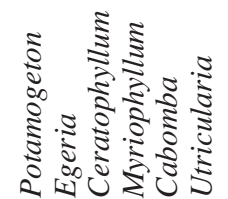
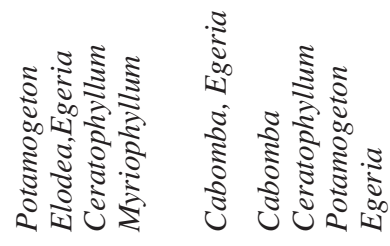

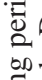

웅 实

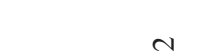

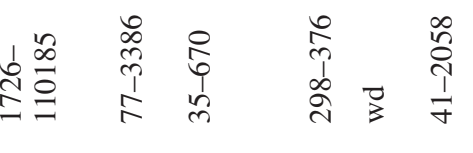

言

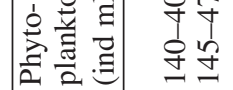

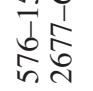

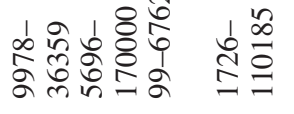

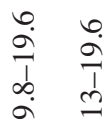

宅。

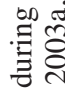

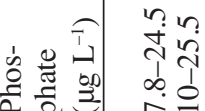

एव

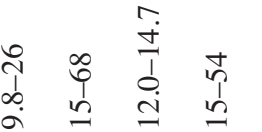

两

彭势

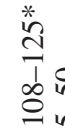

(⿻)

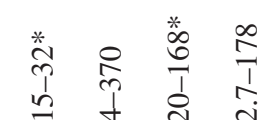

巻

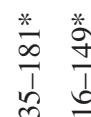

政

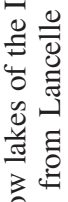

离部

मे

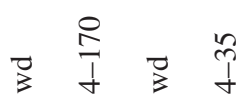

范

$\vec{B} \vec{B}$

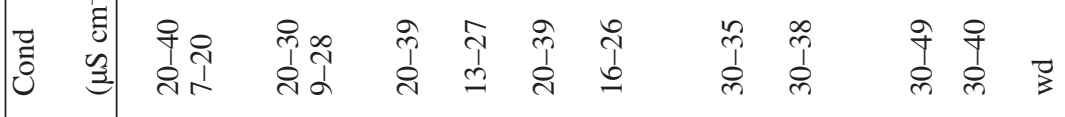

高

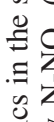

站事

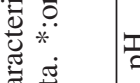

炡

要言

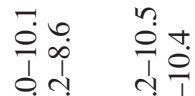

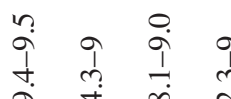

ㅇ.

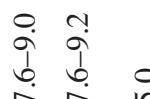

- $\Rightarrow$ - 0

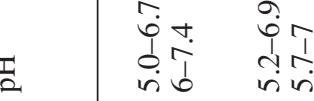

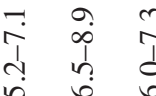

ब.

$\therefore r$

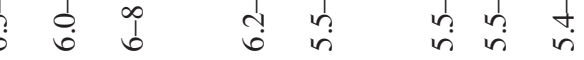

要患

政造

पे

$\stackrel{\infty}{\text { 스 }}$

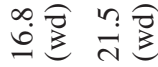

एँ

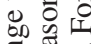

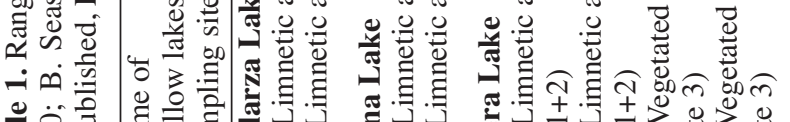

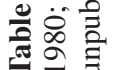

远

युत क्षे

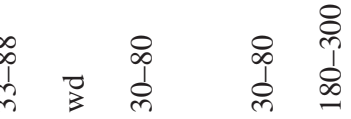

¿ำ

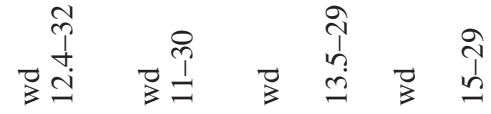

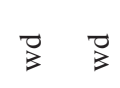

$\bar{B} \bar{B}$

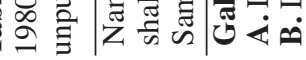




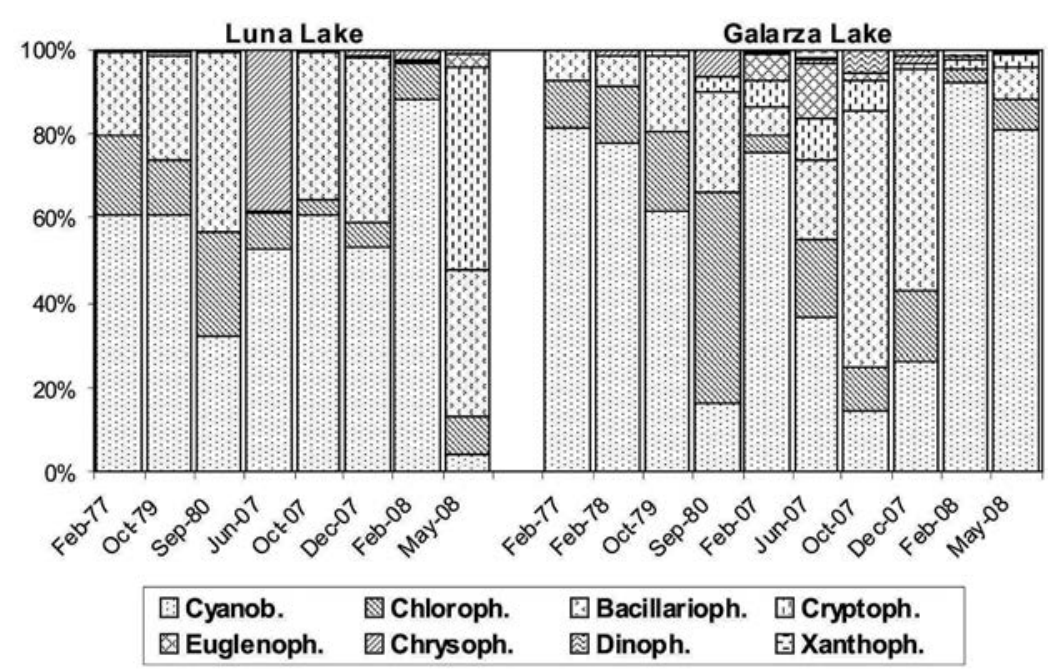

Fig. 3. Relative density of the main taxonomic groups of phytoplankton of Luna and Galarza lakes.

filamentous Cyanobacteria dominated (61-82\%), with Planktolyngbya limnetica and $P$. contorta from S1 (sensu Reynolds et al. 2002) functional classification, here in after bold letters indicate the coda of functional groups). Other filamentous forms, such as Cylindrospermopsis raciborskii, Raphidiopsis mediterranea and $R$. curvata $\left(\mathrm{S}_{\mathrm{N}}\right)$, and globular forms from Aphanocapsa elachista (K) and Microcystis aeruginosa (M), were recorded in low percentages. In the Luna Lake, S1 dominated during the 2007-2008 summer sampling, and cyanobacteria density was $\sim$ twice that observed 30 years ago in 1977-1980 (Zalocar de Domitrovic 2003). In contrast, the Galarza Lake did not show any differences in density in relation to previous studies, probably because it functions as an intermediate basin for water circulation towards the Luna Lake. Chlorophyceae alternated the subdominance with Bacillariophyceae. The best represented taxa were Chlorella sp., Monoraphidium contortum (X1), M. tortile, Scenedesmus ecornis, Desmodesmus communis, Actinastrum hantzschii (J), Cyclotella meneghiniana (C), Ulnaria acus, Fragilaria rumpens (D), Eunotia spp. (TD), Cosmarium moniliforme, Staurastrum spp. and Staurodesmus spp. (NA). The latter was constituted by small isodiametric Desmidiaceae tolerant to nutrient deficiency and mild light (Souza et al. 2008).

A higher diversity of taxonomic and functional groups (although in lower density) was recorded at sites near the areas with 'embalsados' in both shallow lakes. In addition to the previously mentioned assemblages, Mallomonas sp. (E), Cryptomonas sp., C. marsonii, $C$. ovata (Y), Dictyosphaerium ehrenbergianum, Botryococcus braunii (F), Aphanocapsa sp. (K), Merismopedia tenuissima (Lo) and diatoms of genera Eunotia, Pinnularia, Vanheurckia, Navicula (TD) were observed. Euglena fusca, Euglena sp. (W1), Trachelomonas volvocina, T. armata, T. kellogii (W2), Peridinium sp. (Lo) and Mallomonas sp. (E) were generally found sporadically and in low density.

Iberá Lake. In the southern area, it shows a narrow section where the construction of a bridge acts as a barrier hindering water exchange between the two sections of the lake. The 
large northern section ( $80 \%$ of the total surface) does not have submerged vegetation (limnetic area) and water transparency is low. The southern section (vegetated area) shows high water transparency and submerged vegetation (Cabomba sp., Egeria sp., Utricularia sp., among others).

Phytoplankton density was high throughout the year, showing the maximum values of all the Iberá system. Cyanobacteria (Nostocales $>$ Oscillatoriales $>$ Chroococcales), Chlorophyceae (Chlorococcales - Desmidiaceae), Bacillariophyceae (centrics $\leftrightarrow$ pennates), and Cryptophyceae characterized phytoplankton (Fig. 4). Cyanobacteria were dominant during most of the year with Cylindrospermopsis raciborskii $\left(\mathrm{S}_{\mathrm{N}}\right)$ in 2007-2008 samplings. There was a coexistence of Planktolyngbya limnetica and P. contorta (S1) in low percentage. These assemblages are shade tolerant (Reynolds 2006) and disperse throughout the water column. The latter species, together with Raphidiopsis mediterranea, were dominant in 1977-1980 samplings. Cózar et al. (2003) pointed out the dominance of P. limnetica in 1999-2000 samplings. Other functional groups represented in low density were mucilaginous colonial forms from K (Aphanocapsa elachista), Lo (Gomphosphaeria lacustris, Merismopedia tenuissima) and $\mathrm{M}$ (Microcystis aeruginosa).

Between 1977 and 1980, Chlorophyceae and Bacillariophyceae were the subdominant groups in the non vegetated area of the northern section. The main functional groups were X1 (Monoraphidium contortum), J (Scenedesmus ecornis, Scenedesmus spp.), F (Dictyosphaerium ehrenbergianum, Oocystis lacustris), D (Ulnaria acus) and NA (Cosmarium spp., Staurodesmus spp., Staurastrum spp.). In the southern end of the shallow lake (vegetated area), Chlorophyceae predominated represented by Actinastrum hantzschii (J), Staurodesmus triangularis, Staurastrum spp. and Cosmarium moniliforme (NA) in summer, and by Mougeotia sp. (T) and Monoraphidium contortum (X1) in winter. Euglenophyceae was qualitatively

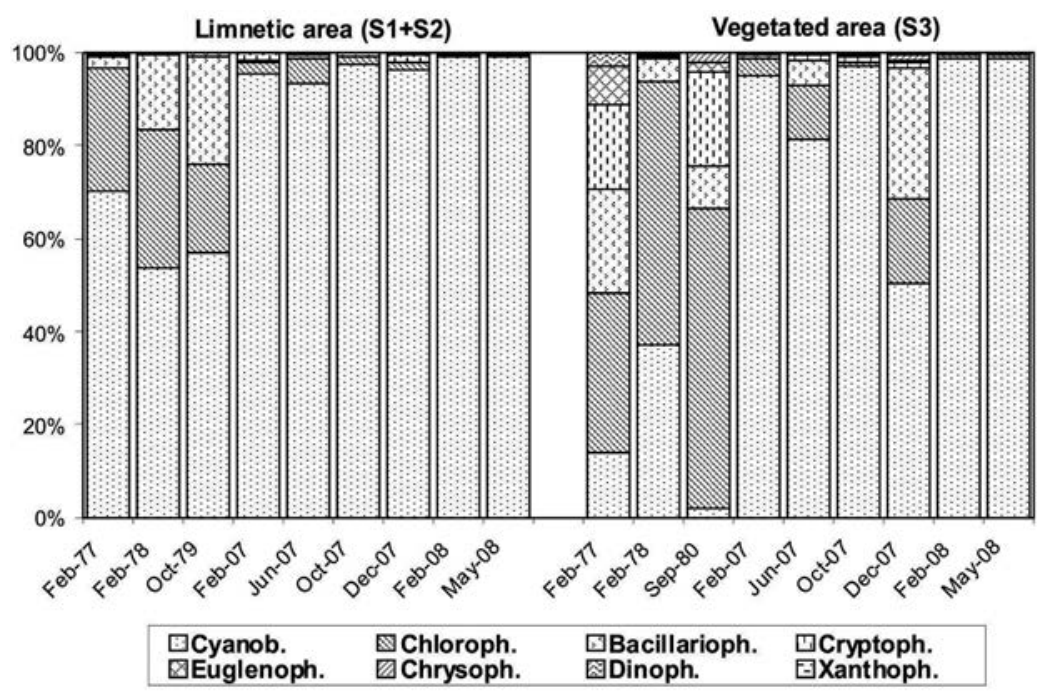

Fig. 4. Relative density of the main taxonomic groups of phytoplankton of Iberá Lake. Limnetic area (S1: North Site + S2: Piedraplen Site), Vegetated area (S3: South Site). 
the most important group and was related to the high content of $\mathrm{OM}$ at this site, which is affected by the Miriñay Channel discharges with high concentrations of humic substances (Neiff 2003b). This group was characterised by Euglena proxima, E. acus, Phacus orbicularis (W1), Trachelomonas volvocina and T. armata (W2).

In 2007-2008, an increase in Cyanobacteria, with dominance of Cylindrospermopsis raciborskii, was observed all along the lake (Fig. 4). It was probably related to an increase in its trophic degree (Cózar et al. 2003) caused by the presence of a human settlement (Colonia Carlos Pellegrini) in the east margin, which currently promotes ecotourism. C. raciborskii is a highly competitive species in eutrophic environments. It has its optimum development in spring and summer when temperatures are high, and the production of toxins may risk the quality of water for consumption (Chorus \& Bartram 1999). The great expansive capacity of this species would probably be related to global warming (Padisák 1997). The proliferation of cyanobacteria was similar to that recorded in spring and summer in shallow lakes with similar limnological characteristics (e.g. Riachuelo and Santa Lucía rivers basins) in the NW of the Corrientes province (Zalocar de Domitrovic et al. 1998a, Asselborn et al. 1999).

In all the studies here surveyed (1977-1980, 2007-2008), species diversity was low in the limnetic area: between 2.2 and 3.5 by dominance of dense populations of Planktolyngbya limnetica and P. contorta in the Luna and Galarza lakes and Cylindrospermopsis raciborskii in the Iberá lake. Diversity was high in the vegetated area of the Iberá lake (between 4.5 and 5), with the exception of the 2007-2008 samplings when values decreased to 1.6 due to the dominance of $C$. raciborskii .

Southwestern shallow lakes. The shallow lakes are long, with clear waters and abundant submerged vegetation ( $40-70 \%$ of their area). The vegetated areas, protected by the wind generate conditions for the development of phytoplankton which is quali-quantitatively different from that of limnetic areas or the northeastern shallow lakes of the system, described previously.

In the Fernández lake, phytoplankton density was higher in the limnetic area, where enhanced light and nutrient availability favoured algal development as compared to the vegetated area, where the macrophytes community is responsible for the flux of nutrients and energy (Neiff 2004). In contrast with that observed in the northeastern lakes, Cyanobacteria density was low and did not exceed $40 \%$ of total abundance in summer. Bacillariophy-ceae (centrics $>$ pennates) and Chlorophyceae (Chlorococcales $>$ Desmidiaceae) characterised phytoplankton. Bacillariophyceae predominated in winter (62\%) and spring (47\%) with Nitzschia acicularis, Synedra spp. (D), Aulacoseira granulata (P) and Cyclotella meneghiniana (C). Chlorophyceae predominated in summer (47\%) with Monoraphidium contortum (X1), Desmodesmus communis, Coelastrum sphaericum, Pediastrum duplex (J), Cosmarium moniliforme, Staurastrum spp., Staurodesmus divergens (NA), Microspora sp. (T), Bulbochaete sp. and Desmidium spp. (TD).

There was a higher number of species in the vegetated area (356) than in the limnetic area (132). The submerged vegetation supports a rich phycoflora of epiphyton and metaphyton (Zalocar de Domitrovic 2003).

The Medina and Trin lakes are next to the Fernández Lake, and are characterised by their clear waters and submerged vegetation. The Carambolas Stream draining an extensive area of marshes and wetlands in the north of the system flows into the northern extreme of the Medina Lake (Fig. 1). 
Phytoplankton density was low (Table 1). No dominance of a particular group was observed in the Medina Lake, except at the end of the winter when Bacillariophyceae predominated, with up to $62 \%$ of total phytoplankton. In the Trin Lake, Chlorophyceae dominated by the beginning of spring and Bacillariophyceae dominated in winter (higher than 70\%).

In both shallow lakes, Chlorophyceae were represented by Monoraphidium contortum, M. tortile (X1), Sphaerozosma laeve, Desmidium swartzii and Spondylosium pulchrum (TD). Bacillariophyceae predominated in density with Ulnaria acus (D). Moreover, a high number of species from functional group TD (Eunotia monodon, E. formica, Gomphonema parvulum, Pinnularia latevitatta, Pinnularia spp., among others) was recorded, although in low percentage. The tychoplanktic forms were probably associated with submerged vegetation, which is abundant and varied in these environments. Other groups, such as Chrysophyceae, Dinophyceae, Euglenophyceae, Cryptophyceae and Cyanobacteria, were in low density.

\section{Comparative analysis of the shallow lakes}

In the three south western shallow lakes of the system, diversity was generally high, between 3 and 5 bits ind. ${ }^{-1}$. In the Fernández Lake, the reduction of diversity in the limnetic area in spring and winter was due to a decrease in species richness, with dominance of diatoms, also observed in the spring sampling. In the Trin Lake, Eunotia monodon showed a maximum population development in the winter sampling, which produced the minimum diversity recorded in this environment.

Phytoplankton density was higher in lakes of the Northeast (Luna, Galarza and Iberá lakes) than in those of the Southwest (Fernandez, Medina and Trin lakes) (Mann-Whitney U test $=191 ; p=0.003$ ).

In the species dendrogram ( 27 algal taxa with density $\geq 30 \%$ in each sample, from a total of 8 samplings), Group I is characterized by high density of Cyanobacteria, with dominance of Planktolyngbya limnetica and P. contorta in the Luna and Galarza lakes, and Cylindrospermopsis raciborskii in the Iberá Lake (Fig. 5). The Group II represents assemblages of species common to most environments, but with higher abundance in the Northeast shallow lakes of the system. Group III, in contrast, characterizes the Southwest shallow lakes: Fernández, Medina and Trin lakes, including some winter samplings of the vegetated area (Site 3: South) of the Iberá Lake.

The differences in density and species richness of phytoplankton between northeastern and southwestern shallow lakes of the Iberá system were also observed in other communities such as zooplankton, benthos and invertebrates associated to submerged macrophytes (Bechara \& Varela 1990, Poi de Neiff 1992, Frutos 2003). The great development of submerged vegetation towards the south of the Ibera system was one of the most important factors related to the decrease in algal abundance. Among the submerged meadows, water circulation is reduced, light transmission is interfered by density of leaves, and this determines that, at depths lower than $50 \mathrm{~cm}$, less than $20 \%$ of light received from the surface reaches that level (Neiff 2003b). Green algae showed the highest number of taxa, from which $65 \%$ corresponded to Desmidiaceae. Their representatives were confined in their distribution to slightly acid or neutral waters with low conductivity, as those found in Iberás environments and in the northwestern shallow lakes. Most Desmidiaceae observed here were tychoplanktic 


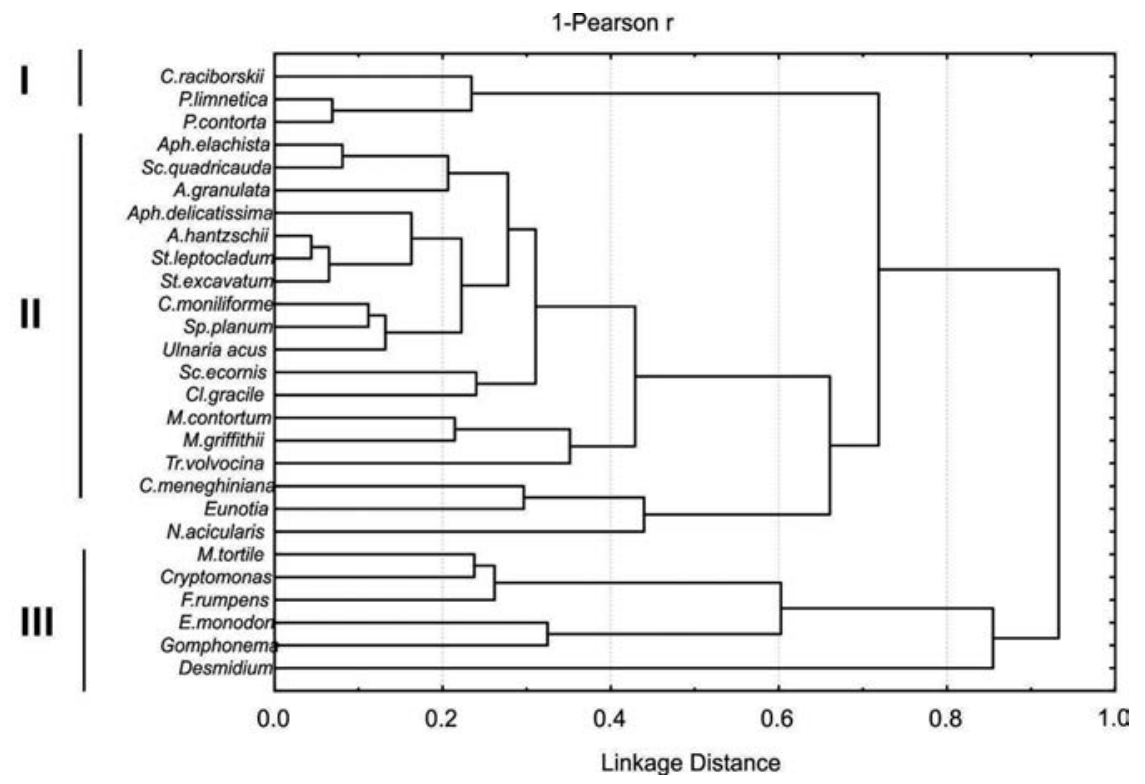

Fig. 5. Dendrogram of algal assemblages from lakes of Iberá system resultant from the between-species cluster analysis.

or benthic forms (Micrasterias foliacea, M. rotata, Triploceras gracile, Gonatozygon spp., Spondylosium spp., Closterium sp., Staurastrum brasiliense, Staurastrum spp.). The greatest variety of species of this group is usually related to the higher richness of submerged macrophytes and to the bioforms they present. Therefore, the more diverse the aquatic vegetation and/or the higher number of divisions in the leaves, the higher the offer of microhabitats for their development (Coesel 1982, Zalocar de Domitrovic 2003).

\section{Swamps}

These environments occupy approximately 75\% of Iberá's total surface (Fig. 1). Neiff (1977) points out the following proportion of aquatic environments: swamps $6750 \mathrm{~km}^{2}$, shallow lakes $323 \mathrm{~km}^{2}$ and water courses $77 \mathrm{~km}^{2}$.

There is a clear difference between the phytoplankton of shallow lakes and the algal community that lives in the adjacent swamps. Within the 'embalsados' of the Galarza, Iberá and Trin lakes, the interstitial water is more acid ( $\mathrm{pH}$ between 4 and 6) than in the limnetic area, which would respond to decomposition processes of organic matter in soils. In comparison, water oxidability and colour are higher in the interstitial water. The chestnut-coloured water (80-160 Pt-Co) is due to the abundance of dissolved humic compounds (Neiff 2003a).

Phytoplankton from the swamps was commonly dominated by small Chlorophyceae and Cryptophyceae. Chlorella spp. and Ankyra judayi, belonging to the functional group X1 (tolerant to limited light and with high metabolism), were the most important species, followed 
by Chloromonas spp. (X2) and Cryptomonas spp. (Y). Among swamps of the Luna and Galarza lakes, there were no Cyanobacteria, possibly due to the sensitivity of this group to conditions of higher acidity. Density and species diversity were lower than in the limnetic area. A distinct feature of the swamps is the development of the functional group WS ( $\sim 60 \%$ in some samplings), represented by Synura spp. Moreover, a varied number of filamentous algae (tychoplanktonic), Mougeotia, Ulothrix and Zygnema (TD), were observed. The Euglenoids from functional groups W1 (Euglena spp.) and W2 (Trachelomonas armata var. steinii, Tr. megalacantha) reach important percentages in biomass, probably favoured by the high organic matter and nutrient concentrations. Xanthophyceae of genus Ophiocytium, probably released from some macrophyte substrate, were frequently observed. Diatoms were represented by Rhopalodia gibba and Cocconeis placentula var. euglypta (TD). The species composition was similar to that observed in other swamps related to the Riachuelo River basin in the NW of the Iberá system and Corrientes province (Bonetto et al. 1978, Zalocar de Domitrovic et al. 1998b).

\section{Marshes}

These environments are interphases between swamps' lacustrine areas and mainland. They occupy a smaller surface than the swamps and are found in the western region of the Iberá system and in the Corriente River margins (Neiff 2004). Thay have similar physico-chemical characteristics to those of swamps. There is no true plankton and the microalgal community is characterized by Xanthophyceae (Vaucheria sp., Tribonema sp.), Bacillariophyceae (pennates $>$ centrics), Chlorophyceae (Oedogoniales $>$ Chaetophorales $>$ Zygnemataceae) and Euglenophyceae (Euglena deses).

\section{Lotic environments}

The growth of algal populations that are part of the plankton of lotic and lenitic environments is regulated by similar environmental factors, which are substantially modified in the former as a result of the unidirectional flow, causing periodic changes in their biotic and abiotic characteristics. A general characteristic in these environments is the low density of phytoplankton as compared to shallow lakes. The Carambolas and Caenguá streams and Miriñay Channel (Fig. 1) drain extensive swamps areas and they have slow flow and marginal vegetation. Chlorophyceae, Cryptophyceae and Bacillariophyceae characterized the phytoplankton. There is not a true potamoplankton, which is confined to large rivers as the Paraná and Paraguay rivers (Devercelli et al. 2014, Zalocar de Domitrovic 2014a, b). The functional groups here recorded belong to X1 (Monoraphidium tortile, M. griffithii), J (Parapediastrum biradiatum), Y (Cryptomonas spp.), TD (Mougeotia sp.), MP (Closterium setaceum), N (Cosmarium binum) and TD (Eunotia, Synedra, Ulnaria, Cymbella, Vanheurckia, Cocconeis).

The diversity was high in spring and summer (between 3 and 5 bits ind. ${ }^{-1}$ ), decreasing in winter due to a reduction in species richness. Minimum values were recorded in the Miriñay Channel (1.8), with intermediate values in the Caenguá and Carambolas streams. 
The Corriente River born at the SW of the Iberá system and drains this large wetland flowing into the Middle Paraná River. The phytoplankton density and species richness upstream was higher than that recorded $\sim 40 \mathrm{~km}$ downstream. Chlorophyceae was the most important group represented by Chlorococcales and Zygnematales (Desmidiaceae). Bacillariophyceae, Cryptophyceae, Cyanobacteria and Euglenophyceae may achieve either qualior quantitative importance at certain seasons of the year, depending on discharge. The highest species richness corresponds to Desmidiaceae that are almost reduced to half at downstream reaches. This may respond to the selective action produced by water current, removing a group adapted to other limnological conditions (Köhler 1994). In contrast, Chlorococcales and centric diatoms increase downstream and comprise opportunistic species of small size and rapid reproduction (X1) and diatoms (C), which have adaptations to grow under low light intensities (Reynolds 2006). These assemblages are commonly found in small lowland rivers (e.g. Yang et al. 1997, Salmaso \& Braioni 2007). Cyanobacteria and Euglenophyceae, which are generally scarcely represented in pristine river plankton, were abundant in summer by functional groups $\mathrm{S}_{\mathrm{N}}$ (Cylindrospermopsis raciborskii and Raphidiopsis spp.) and W1 (Euglena oxyuris, Euglena spp.).

Overall, in the analyzed lotic environments, the highest diversity was found in the Corriente River, in coincidence with high species richness. The Corriente River, the most important of the Iberá system because of its flow and length, shows higher abundance and variety of tychoplanktic species (characteristic of swamps and shallow lakes) in its headwaters than downstream next to its mouth, due to the selectivity of plankton tolerant to hydraulic stress.

\section{Final remarks}

In the Iberá system, the northeastern shallow lakes (Luna, Galarza and Iberá lakes) are characterized by low diversity and high phytoplankton density with dominance of Cyanobacteria. Twenty three functional groups were represented, with predominance of $\mathrm{S}_{\mathrm{N}}$ (Cylindrospermopsis raciborskii) and S1 (Planktolyngbya limnetica and P. contorta). In Iberá's southwestern shallow lakes (Fernández, Medina and Trin lakes), the phytoplankton density was low and diversity was high. The registered taxa were sorted into 28 functional groups, mainly X1 (Monoraphidium contortum, M. tortile), J (Desmodesmus communis, Coelastrum sphaericum, Pediastrum duplex), NA (Cosmarium moniliforme, Staurastrum spp., Staurodesmus divergens) and TD (Sphaerozosma laeve, Desmidium swartzii, Spondylosium pulchrum, Eunotia monodon, E. formica, Gomphonema parvulum, Pinnularia spp.)

About 1000 taxa were observed in the phytoplankton of the Iberá system (Zalocar de Domitrovic 2003). The contribution of the number of species is given by four taxonomic groups: Chlorophyceae (600), Bacillariophyceae (150), Euglenophyceae (166) and Cyanobacteria (65). The rest of the groups recorded a lower number: Xanthophyceae (13), Cryptophyceae (6), Chrysophyceae (6) and Dinophyceae (4). Iberás phycoflora, as that of the other waterbodies of the NW of Corrientes province, is different from that from Chaco region (Zalocar de Domitrovic 2014b). When the Paraná River flowed by the Iberá-Corriente River depression in the Middle Pleistocene (Popolizio 1977) it probably acted distributing species coming from other areas. The Argentine northeast (Mesopotamia) constitutes a unique region in Argentina with a high number of endemic species, centralized in the Iberá system, one 
of the most important biodiversity reservoirs in South America. Considering the number of studied environments, algal diversity in each region was related to the surface occupied by waterbodies. Therefore, the highest diversity was confined to the large wetlands as the Iberá's system in the province of Corrientes (in this article) and those wetlands in the eastern Chaco region (Zalocar de Domitrovic 2014b).

\section{References}

Asselborn, V. M., Zalocar de Domitrovic, Y. \& Casco, S. L. (1999): Estructura y variaciones del fitoplancton de la laguna Soto (Corrientes, Argentina). - Bol. Soc. Arg. Bot. 33(3-4): 17-27.

Bechara, J. A. \& Varela, M. E. (1990): La fauna bentónica de lagunas y cursos de agua del sistema Iberá (Corrientes, Argentina). - Ecosur 16(27): 45-60.

Bonetto, A. A., Neiff, J. J., Poi de Neiff, A., Varela, M. E., Corrales, M. A. \& Zalocar, Y. (1978): Estudios limnológicos en la cuenca del Riachuelo (Corrientes, Argentina). III Laguna La Brava. Ecosur 5(9): 57-84.

Bruniard, E. D. (1981): El clima de las planicies del norte argentino. - Ph. D. Thesis. Universidad Nacional del Nordeste. Resistencia, Chaco, 379 p.

Canziani, G. A., Ferrati, R. S., Rossi, C. \& Ruiz-Moreno, D. (2006): The influence of climate and dam construction on the Ibera wetland, Argentina. - Reg. Environ. Change 6: 181-191.

CECOAL (Centro de Ecología Aplicada del Litoral) (1981): Estudio del macrosistema Iberá. - Vol. 1-2. Bonetto, A. A. (ed.). ICA-CECOAL, Corrientes, Argentina.

Chorus, I. \& Bartram, J. (1999): Toxic Cyanobacteria in water. A guide to their public health consequences, monitoring and management. - WHO, E \& FN Spon, London.

Coesel, P. F. M. (1982): Structural characteristics and adaptations of desmid communities. - J. Ecol. 70: $163-177$.

Cózar, A., García, C. M. \& Gálvez, J. A. (2003): Analysis of plankton size spectra irregularities in two subtropical shallow lakes (Esteros del Iberá, Argentina). - Can. J. Fish. Aquatic. Sci. 60: 411-420.

Devercelli, M., Zalocar de Domitrovic, Y., Forastier, M. E. \& Meichtry de Zaburlín, N. (2014): Phytoplankton of the Paraná River. - Adv. Limnol. 65: 39-65.

Ferrati, R., Canziani, G. A. \& Ruiz-Moreno, D. (2005): Esteros del Ibera: hydrometeorological and hydrological caracterization. - Ecol. Modell. 186: 3-16.

Frutos, S. M. (2003): Zooplancton de lagunas y cursos de agua del sistema Iberá. - In: Poi de Neiff, A. S. G. (ed.): Limnologia del Iberá: Características físicas, químicas y biológicas de las aguas, pp. 143-151. Eudene, Corrientes, Argentina.

Köhler, J. (1994): Origin and succession of phytoplankton in a riverlake system (Spree, Germany). Hydrobiologia 289: 73-83.

Lancelle, H. G. (2003): Características físicas y químicas de las aguas del Iberá. - In: Poi de Neiff, A. S. G. (ed.): Limnologia del Iberá: Características físicas, químicas y biológicas de las aguas, pp. 71-84. Eudene, Corrientes, Argentina.

Neiff, J. J. (1977): Investigaciones ecológicas en el complejo de la laguna Iberá en relación a diversas formas de aprovechamiento hídrico. Seminario sobre medio ambiente y represas. - OEA. Universidad de la República. Montevideo, Uruguay, Tomo I: 70-87.

Neiff, J. J. (2003a): Los ambientes acuáticos y palustres del Iberá. - In: Poi de Neiff, A. S. G. (ed.): Limnología del Iberá: Características físicas, químicas y biológicas de las aguas, pp. 3-16. Eudene, Corrientes, Argentina.

Neiff, J. J. (2003b): Distribución de la vegetación acuática y palustre del Iberá. - In: Poi de Neiff, A. S. G. (ed.): Limnología del Iberá: Características físicas, químicas y biológicas de las aguas, pp. 17-70. Eudene, Corrientes, Argentina.

Neiff, J. J. (2004): El Iberá ¿En peligro? - Fundación Vida Silvestre Argentina, Buenos Aires, 89 pp. 
Orfeo, O. (2005): Historia geológica del Iberá como escenario de biodiversidad. - In: Aceñolaza F. G. (ed.): Temas de la Biodiversidad del Litoral Fluvial Argentino II. Miscelánea 14: 71-78. INSUGEO. Argentina.

Padisák, J. (1997): Cylindrospermopsis raciborskii (Woloszynska) Seenayya et Subba Raju, an expanding, highly adaptative cyanobacterium: worldwide distribution and review of its ecology. Arch. Hydrobiol. Suppl., Monogr. Stud. 107: 563-593.

Poi de Neiff, A. S. G. (1992): Invertebrados asociados a los macrófitos sumergidos de los esteros del Iberá (Corrientes, Argentina). - Amb. Subtrop. 2: 45-63.

Poi de Neiff, A. S. G. (ed., 2003): Limnología del Iberá: Características físicas, químicas y biológicas de las aguas. - Eudene, Corrientes, Argentina.

Popolizio, E. (1977): Contribución a la geomorfología de la provincia de Corrientes (Argentina). Geociencias 7: 1-45.

Reynolds, C. S. (2006): Ecology of phytoplankton. - Cambridge Univ. Press, Cambridge.

Reynolds, C. S., Huszar, V., Kruk, C., Naselli-Flores, L. \& Melo, S. (2002): Towards a functional classification of the freshwater phytoplankton. - J. Plankton Res. 24: 417-428.

Salmaso, N. \& Braioni, M. G. (2007): Factors controlling the seasonal development and distribution of the phytoplankton community in the lowland course of a large river in Northern Italy (River Adige). - Aquat. Ecol. 42: 533-545.

Scheffer, M. (1998): Ecology of shallow lakes. - Chapman \& Hall, London.

Souza, M. B. G., Barros, C. F. A., Barbosa, F., Hajnal, E. \& Padisák, J. (2008): Role of atelomixis in replacement of phytoplankton assemblages in Dom Helvécio Lake, South-East Brazil. Hydrobiologia 607: 211-224.

Tell, G. (2014): Phytoplankton diversity. - Adv. Limnol. 65: 5-20.

Yang, J. R., Basu, B. K., Hamilton, P. B. \& Pick, F. R. (1997): The development of a true riverine phytoplankton assemblage along a lake-fed lowland river. -Arch. Hydrobiol. 140: 243-260.

Zalocar de Domitrovic, Y. (2003): Fitoplancton de lagunas y cursos de agua del sistema Iberá. - In: Poi de Neiff, A. S. G. (ed.): Limnología del Iberá: Características físicas, químicas y biológicas de las aguas, pp. 85-142. Eudene, Corrientes, Argentina.

Zalocar de Domitrovic, Y., Asselborn, V. M. \& Casco S. L. (1998a): Variaciones espaciales y temporales del fitoplancton en un lago subtropical de Argentina. - Rev. Brasil. Biol. 58: 359-382.

Zalocar de Domitrovic, Y., Casco, S. L. \& Asselborn, V. M. (1998b): Estudio de la biomasa y diversidad del fitoplancton de la laguna Paiva, Corrientes (Argentina). - Physis (Bs. As.) Sec. B 55(128-129): $1-13$.

Zalocar de Domitrovic, Y., Devercelli, M. \& Forastier, M. E. (2014a): Phytoplankton of the Paraguay and Bermejo rivers. - Adv. Limnol. 65: 67-80.

Zalocar de Domitrovic, Y., Devercelli, M. \& Forastier, M. E. (2014b): Phytoplankton of the ChacoPampean. - Adv. Limnol. 65: 81-98. 
